\title{
Translations and interpretations of baptizontes (Mt 28:19-20) in some Ghanaian mother tongue translations of the Bible
}

\begin{tabular}{|c|c|}
\hline \multicolumn{2}{|c|}{$\begin{array}{l}\text { Author: } \\
\text { Jonathan E.T. Kuwornu- } \\
\text { Adjaottor }^{1,2} \text { (D) }\end{array}$} \\
\hline \multicolumn{2}{|c|}{$\begin{array}{l}\text { Affiliations: } \\
{ }^{1} \text { Department of Religious } \\
\text { Studies, Faculty of Social } \\
\text { Sciences, Kwame Nkrumah } \\
\text { University of Science and } \\
\text { Technology, Kumasi, Ghana }\end{array}$} \\
\hline \multicolumn{2}{|c|}{$\begin{array}{l}{ }^{2} \text { Department of New } \\
\text { Testament and Related } \\
\text { Literature, Faculty of Theology } \\
\text { and Religion, University of } \\
\text { Pretoria, Pretoria, South Africa }\end{array}$} \\
\hline \multicolumn{2}{|c|}{$\begin{array}{l}\text { Research Project Registration: } \\
\text { Project Leader: E. van Eck (®) } \\
\text { Project Number: } 2400030\end{array}$} \\
\hline \multicolumn{2}{|c|}{$\begin{array}{l}\text { Description: } \\
\text { This research is part of the } \\
\text { research project 'Africa } \\
\text { Platform for NT Scholars', } \\
\text { directed by Prof. Dr Ernest } \\
\text { van Eck, Department of } \\
\text { New Testament Studies and } \\
\text { Related Literature, Faculty } \\
\text { of Theology and Religion, } \\
\text { University of Pretoria. }\end{array}$} \\
\hline \multicolumn{2}{|c|}{$\begin{array}{l}\text { Corresponding author: } \\
\text { Jonathan Kuwornu-Adjaottor, } \\
\text { jkadjaottor@gmail.com }\end{array}$} \\
\hline \multicolumn{2}{|c|}{$\begin{array}{l}\text { Received: } 21 \text { May } 2021 \\
\text { Accepted: } 22 \text { July } 2021 \\
\text { Published: } 22 \text { Sept. } 2021\end{array}$} \\
\hline \multicolumn{2}{|c|}{$\begin{array}{l}\text { How to cite this article: } \\
\text { Kuwornu-Adjaottor, } \\
\text { J.E.T., 2021, 'Translations } \\
\text { and interpretations of } \\
\text { baptizontes (Mt 28:19-20) } \\
\text { in some Ghanaian mother } \\
\text { tongue translations of the } \\
\text { Bible', HTS Teologiese } \\
\text { Studies/Theological Studies } \\
\text { 77(1), a6859. https://doi. } \\
\text { org/10.4102/hts.v77i1.6859 }\end{array}$} \\
\hline \multicolumn{2}{|l|}{ Read online: } \\
\hline 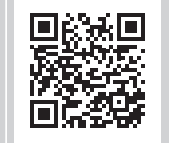 & $\begin{array}{l}\text { Scan this QR } \\
\text { code with your } \\
\text { smart phone or } \\
\text { mobile device } \\
\text { to read online. }\end{array}$ \\
\hline
\end{tabular}

Scholars have written on Jesus' command to make disciples, but little work has been done on the translation of baptizontes. Using the mother-tongue biblical hermeneutics approach, this article analyses the translation of baptizontes in 12 Ghanaian mother tongue Bibles. The findings are that the various Ghanaian mother tongue translations of Matthew 28:19 render baptizontes variedly, to suit the indigenous Bible readers. Translators sometimes use religiocultural words and phrases that express a similar idea in their contexts to translate the word. Thus, Bible translation always involves interpretation. Translators sometimes coin their own words or consult mother tongue speakers for information in order to render words and phrases that are difficult to translate. This article has added an African (Ghanaian) interpretation of baptizontes in Matthew 28:19. This fits into the overall aim of the journal to promote African theology.

Contribution: This article makes a contribution to the Special Collection 'Africa Platform for NT Scholars' on the Ghanaian (African) interpretations of baptizontes in Matthew 28:19-20.

Keywords: Bible; translation; interpretation; Ghana; Africa; Matthew 28:19-20.

\section{Introduction}

Baptism is not a distinctive or uniquely Christian idea. The practice of baptism is widespread. Examples include the Hindu rituals in the Babylonian cult Enki, and the Egyptian practices of purifying newborn children and the symbolic revivification rites performed on the dead. Baptizo and related terms were used to define ritual practices in early Cretan religion, Thracian religion, Eleusinian mystery religions and in several gnostic groups and cults. Common elements are associated with these widespread baptismal practices. Except when used metaphorically, baptism is always associated with water. Baptism is performed in connection with the removal of guilt, cleansing and the granting of a new start. Christian baptism shares these common traits and contexts; it also has specific historical contexts and theological significance that give it a distinctive Christian meaning.

Followers of John or Jesus who participated in the baptismal rite, whether Jew or Gentile, would not have found this practice totally unfamiliar. Water is the element naturally used for cleansing the body; its symbolic use entered into almost every religious practice, and none more completely than Jewish practices. The purification rituals of Judaism stressed cleanliness and worthiness to serve the Lord ( $\mathrm{Lv} 13-17, \mathrm{Nm} 19)$ The ritual of washing was similar to baptism in its purifying implications (Mk 7:4, Heb 9:20). In Psalm 51:2 and 7, the psalmist asks for divine cleansing. Especially significant is Isaiah $4: 4$, which calls for a washing away of sins by the 'spirit of burning', an adumbration of the theme taken up by John in his baptism.

In addition to these OT examples, Jews had a counterpart of the Christian practice in their proselyte rituals. It is not certain when the Jewish proselyte baptism began, some arguing that it began at the same time as the Christian rite (McKnight 1991) and others that it preceded the Christian rite (Beasley-Murray 1962). The account of Naaman the leper, which is possibly a purification washing, is similar to later proselyte baptism. Later it became accepted that male Jewish proselytes were to be baptised in the presence of witnesses 7 days after circumcision. In later traditions Judaism required three things of converts to Judaism: (1) circumcision, (2) baptism or ritual bath and (3) the offering of sacrifice. These rituals of circumcision and washing were most likely preceded by catechetical instruction. The Talmud refers to a baptised proselyte as a newborn child. The distinctive Christian understanding of baptism in terms of dying and rising

Copyright: (C) 2021. The Authors. Licensee: AOSIS. This work is licensed under the Creative Commons Attribution License. Note: Special Collection: Africa Platform for NT Scholars, sub-edited by Ernest van Eck (University of Pretoria). 
is based on the convert's relationship to Christ, who died and rose from the dead (Beasley-Murray 1962).

Reference to Matthew 28:19-20 is often made during church evangelism and missionary activities and often termed as the 'the Great Commission'. This is a term used to explain the above scripture as a commandment from Jesus Christ. The Great Commission is a command to Christians to make disciples (matheteusate), introduce and initiate members into Christendom by means of baptising them (baptizontes) whilst teaching them the dictates, principles and observations of the Bible (didaskontes) (Douglass \& Tenney 1989:157). Scholars have written on Jesus' command to make disciples (Bowland 1999; Barna 2001; Kpobi 2008; Olowe 2009; Obeng Adjei 2013; Kwarteng 2020), but little work has been done on the translation of baptizontes. This article analyses the translation of baptizontes in some Ghanaian mother-tongue Bibles.

Bible translation from the source languages to receptor languages is a theological activity. A. Mojola (2013:486-499) gives a pan-African historical overview of Bible translation. Loba-Mkole (2013:508-522) discusses the significance of Bible translations for African theological education. Malulele (2005:488-489) links translation theologies to the names of Lamin Sanneh and Kwame Bediako. Lamin argues that the fact that scripture was translated from Jewish culture (Aramaic and Hebrew) into the Gentile culture (Greek) is enough of a point to establish a pattern for the translation, appropriation and assimilation of languages and cultures. This pattern has theological and cultural ramifications. Sanneh (2009) is of the view that the:

[S] uccess of Christianity will call for education that will bring us new ways of viewing the world, commencing a process of revitalization that reaches into both the personal and cultural spheres. (pp. 52-53)

To Sanneh, the cultural ramifications of the Bible are in its translation into the vernacular of concepts, with the adaptation of indigenous terms, customs and idioms.

Bediako posits that the development of theological concern and the formulation of theological questions are closely linked with identity. He assesses the deep mother tongue roots of large portions of African Christianity and explores the prospects of this modern African experience in the future shape of Christian theological discourse, in the understanding of the nature of Christian history and in Christianity's continual social and cultural impact on the world (Bediako 1995).

\section{Methodology}

The study employs the mother tongue biblical hermeneutics approach. The term 'mother tongue' is a linguistics category that is used to denote origin - the language one learned firstly, in which one has established the first long-lasting verbal contacts. 'Mother tongue' expresses the idea that the linguistic skills of a child are acquired from his or her mother; therefore, the language of the mother would be the primary language that the child would learn. Its importance lies in the fact that it identifies a speaker internally and externally; that is, one identifies with it and is identified with it, even though it may not be the language one knows best and uses most. ${ }^{1}$

Ekem builds on the ideas of Sanneh and Bediako and posits that Bible translations involve exegesis, which should be taken seriously by translators because even though the compiler and addressees of the Judeo-Christian scriptures operated in a pluralistic religious environment like ours, which serves as a hermeneutical point of departure for African biblical exegetes and translators, they may run into difficulties because the contexts are different (Ekem 2003:31-34). He proposes the discipline of biblical interpretation, using viable mother tongue thought categories. ${ }^{2}$ This discipline he refers to as 'mother tongue biblical hermeneutics', a discipline devoted to the interpretation and reinterpretation of biblical texts into languages considered by speakers as their first languages, into which they were born (Ekem 2011:10). Kuwornu-Adjaottor has cited theses and journal articles that have come out as a result of Ekem's proposal (Kuwornu-Adjaottor 2012b:575-580).

Kuwornu-Adjaottor has proposed a methodology for doing mother tongue biblical hermeneutics. It is an eclectic methodology that borrows from the fields of biblical studies, language studies, translation and religiocultural studies: ${ }^{3}$

1. Identify a biblical text which has not been properly translated into your mother tongue.

2. Discuss why the translation is problematic in your culture.

3. State the methodology you will use and the proponents.

4. Do a study (an exegesis) of the text, using Bible study resources - dictionaries, commentaries, encyclopaedias, word study helps, etc.

5. Find out what scholars have said about the text, how they interpret it and the reasons for their interpretations.

6. Discuss the usage in your language/culture; interview indigenous speakers of your mother tongue for deeper insights into the concept you are researching. Use local terminologies in your writing and explain them in English.

7. Compare the text in your mother tongue with other Ghanaian translations you can read and understand.

1.This definition should not be taken without criticism because in some countries such a Kenya, India and various East Asian countries, 'mother tongue' refers to 'moch a Kenya, lndia and various East Asian countries, 'mother tongue' refers to 'mother language' or 'native language' and is used to indicate the language of one's ethnic group, in both common and journalistic parlance, rather than the firs language. Also in Singapore, 'mother tongue' refers to the English language that was established on the island through British colonisation, which is the lingua franca for most post-independence Singaporeans because of its use as the language of instruction in government schools as a working language.

2.Cf. Togarasei (2013:466-474). Togarasei lists five methods for consideration in African Biblical studies/interpretation: the use of a specific method(s); the use of proper methods that achieve the objectives of Africa; the use of African though forms and world views in interpretation, which requires a full engagement with African languages; the need to take seriously popular/ordinary readings from Bible-reading communities.

3.Kuwornu-Adjaottor (2012b:572-579); see ANUJAT (Kuwornu-Adjaottor 2012a:55-80) where this methodology has been referenced under the title, 'Doing Biblical Studies using the Mother tongue Approach', ANUJAT (Kuwornu-Adjaottor 2012a:55-80); using the Mother tongue Approach', ANUJAT (Kuwornu-Adjaottor 2012a:55-80);
also in ERATS (Kuwornu-Adjaottor 2015:1-24) under the title 'African Biblical Studies: Mother tongue Biblical Hermeneutics Methodology'. 
8. Analyse the mother tongue translations; what do they mean? How are the meanings of the text similar to that of the Hebrew/Greek? How are they different? What might have accounted for the differences in translation?

9. Suggest a new translation of the text that fits into your culture.

\section{Meaning of baptizontes (Mt 28:19-20)}

\section{The Greek text}

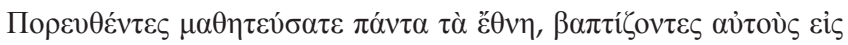

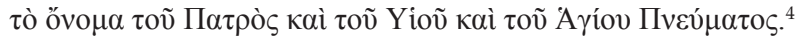

$\boldsymbol{\beta} \boldsymbol{\alpha} \pi \boldsymbol{\tau} \mathbf{\zeta} \mathbf{0 v \tau \varepsilon \varepsilon}$ verb participle present active nominative

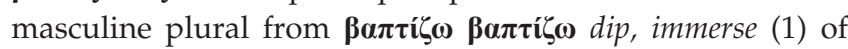
Jewish ritual washings, mid. and pass, wash one's hands Mark 7:4, Luke 11:38. (2) baptize, of ritual immersion by John the Baptist and Christians Matthew 3:11, 13f, 16; 28:19; Mark 6:14, 24; J4:1f; Acts 2:38, 41; 8:12f, 36, 38; 1 Corinthians 1:14-17; 15:29. (3) fig. Matthew 3:11; 1 Corinthians 10:2; 12:13. ${ }^{5}$

\section{Findings}

\section{Translation of baptizontes into some Ghanaian mother tongue versions of the Bible}

In Ghana, out of the 67 mother tongues, ${ }^{6}$ the complete Bible has been translated into 14 and the New Testament (NT) into 27. These translations were done by the Bible Society of Ghana (BSG), ${ }^{7}$ the Ghana Institute of Linguistics, Literacy and Bible Translation (GILLBT) ${ }^{8}$ and the International Bible Society, now known as Biblia. For the article, the researcher selected 12 of the Ghanaian translations of the Bible to find out how the translators rendered baptizontes in them and analyse why the Greek word has been translated as such. The selection is based on six of the languages from Southern Ghana that he understands and speaks; the other six Northern Ghanaian languages are ones that his students understand and speak.

\section{Some Southern Ghanaian translations ${ }^{9}$ of baptizontes}

1. Ngmami Klôuklôu ô (1999).

Sôle mâ. [Pray for them.]

\section{Mattew 28:19 BYZ.}

5.Of martyrdom. Mark 10:38f., 33.

6.Ghana Home Page/Tribes/Languages (http://ghanaweb.com).

7.The BSG has translated and published the Bible in Asante-Twi, Akuapem-Twi, Ga, Mfante, Ewe, Dangme, Dagbani and Nzema and Esahie. The NT has been translated and published in Dagaare. The NT is being translated into Bono. The OT projects in these languages are ongoing. Revision projects on some of the older versions - Ga, Akuapem-Twi, Asante-Twi, Mfantse and Ewe have been completed, and the Bibles have been launched. Revision of the Dangme Bible is ongoing (www.biblesocietyghana.org/what-we-do).

8.GILLBT has translated and published the Bible in five Northern Ghanaian mother tongues: Konkomba, Tampulma, Bimoba, Farefare and Chumburung; it has published the NT in 25 languages: Kusal, Vagla, Sisaala, Nafaanra, Hanga, Frafra, Chumburung, Kasem, Mo (Deg), Buli, Lelemi, Adele, Mampruli, Gikyode, Pasaale, Koma, Ntrubo, Birifor, Anu
(http://www.gillbt.org).

9.The researcher, whose mother tongue is Dangme, speaks, reads and understands The researcher, whose mother tongue is Dangme, speaks, reads and understands
the other languages to a large extent. Dangme is spoken by 800000 people; Ga, 8.5 the other languages to a large extent. Dangme is spoken by 800000 people; Ga, 8.5
million; Ewe, 6.61 million; Mfantse, 2.7 million; Akuapem-Twi, 626000 ; and Asantemillion; Ewe, 6.61 million; Mfantse, 2.7
Twi, 3.8 million (source: Ethnologue).
2. Ngmale Kroåkroå Lâ (2006). Sôle amâ. [Pray for them.]

3. Biblia (2010).

De Mawu tsi ta na wo. [Put God's water on their heads.]

4. Twerew Kronkron (2017).

Mommo won asu. [Throw water at them.]

5. Kyerâw Kronkron (2012).

Mommo won asu. [Throw water at them.]

6. Nwoma Kronkron (1974).

Nnu won. [Dip/immerse them.]

\section{Some Northern Ghanaian translations ${ }^{10}$ of baptizontes}

1. Uwumbôr Aagbaå (2014).

Muin bi nnyun. [Put them deep in the water.]

2. Naawun Bukupali (1983).

Su koom. [Bathe them.]

3. Ebore Be Kawol (1984). Ka boreber. [Bath of God.]

4. Naawuni Kundi Kasi (2011). Baptizibu. [Coined word from 'baptism'.]

5. Yenâ Gôåô (2007). Sôora ba koom. [Bathe them with water.]

6. Naaåmen Nôpaalaa Gane (2014).

Korô ba suobu. [Continue bathing them.]

\section{Analyses of the translations}

The meanings of the translations above are thematised grouped as follows:

1. Baptizontes as 'prayer'. The Dangme and Ga render baptizontes as nyââ sôle mâ and nyââ sôle amâ [pray for them], respectively. This is far from the Greek meaning of the text. Prayer (intercession/supplication) and baptism (dipping into/immersion in) are two different activities. Even though a prayer is said during the baptism of converts, prayer per se is not baptism. In Dangme a phrase like nye mu me nyusi [dip them in water] or nye pue me nyu [put water on them] could be a better rendering of baptizontes.

2. Baptizontes as 'put water on'. The Ewe Bible renders baptizontes as de mawutsi ta na wo [put God's water on their heads]. The translators have bypassed the basic meaning of baptizontes in the text (dipping, immersing) and rendered the word as God's water, which should be placed on the heads of converts to Christianity. The inclusion of God in this matter means that when the ordinary water used for baptism is prayed over, it becomes 'God's water'. Thus, when God's water is

10.The researcher used four of his MPhil and PhD candidates who read and understand these languages. They read the text from the various translations and gave the literal meaning of the words and phrases used to translate baptizontes. Gonja is literal meaning of the words and phrases used to translate baptizontes. Gonja is
spoken by 230000 people; Dagaare, 1.1 million; Hanga, 6800; Konkomba, 500000 ; Farefare, 831; and Dagbani, 3.1 million (source: Ethnologue). 
placed on the head of a convert, that person becomes God's own. Again, it must be stated here that the translators have in mind sprinkling ${ }^{11}$ as a mode of baptism. They considered baptism as a symbol and not merely an arbitrary sign. So they did not base the translation of baptizontes on the linguistic data (Mt 28:19, cf. Jn 3:23, Mk 1:10, Ac 8:36, 38-39).

3. Baptizontes as 'bathe'. Four of the Northern Ghanaian translations - Gonja, Farafara, Hanga and Konkomba render baptizontes as 'bathe'. Three of them state 'bathe', without stating what should be used; the Farafara version, however, states that the baptismal candidates should be bathed with water. In the case of the Farafara version, the translators have added 'water' to the bathing. One can therefore say that washing with water or in water is implied in the other three translations.

4. Baptizontes as 'dip in water'. The Mfantse translation uses nnu won [dip them] for baptizontes. Here, the translators have in mind baptism by immersion. This agrees with the linguistic data (Mt 28:19, cf. Jn 3:23, Mk 1:10, Ac 8:36, 38-39) and refutes the Westminster Confession, which states that ' $[d]$ ipping of the person into water is not necessary; but baptism is rightly administered by pouring or sprinkling water upon the person'. ${ }^{12}$

5. Baptizontes as 'throw water at'. Both the Asante-Twi and Akuapem-Twi translations render baptizontes as mmo won asu [throw water at them]. Water is part of the rendering even though it is not in the Greek text. The translators perhaps may have thought of a practice in Asante and Akuapem shrines where water is thrown at sick people who have received healing to declare them fit to start a new life.

6. Baptizontes as 'baptizibu'. This rendering by the Dagbani translators is basically a literal transliteration of baptizontes, with an -ibu ending, which does not mean anything in Dagbani. Perhaps the translators, for lack of proper terminology in Dagbani to denote baptizontes, settled on baptizibu in order not to land in complexities. Baptizibu neither expresses immersion nor sprinkling as modes of baptism. However, in preparing converts for baptism, the expression that is normally used by the churches is tuba koôm subu [repentance water bathing]. The churches use this expression because of the Islamic background of most Dagomba people. Converts to Islam are washed, to make them acceptable to the religion to start a new life.

\section{The tense of baptizontes}

$\beta \alpha \pi \tau i \zeta o v \tau \varepsilon \varsigma$ is a present participle verb, active nominative masculine plural, from $\beta \alpha \pi \tau i \zeta \omega \beta \alpha \pi \tau i \zeta \omega$ [dip, immerse]. All the Ghanaian mother tongue translations under study render

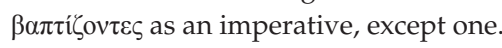

11.John Calvin justified sprinkling as a mode of baptism when he stated that "whether the person baptized is wholly immersed, and that whether once or thrice, or whether he [she] be sprinkled with water, is not of the least consequence: although it is evident that the term baptize means to immerse, and that this was the form used in the primitive church' (Institutes, 4.15.19, Beveridge trans).
Dangme - nyââ sôle mâ [pray for them]; Ga - nyââ sôle amâa [pray for them]; Ewe - mi de mawutsi ta na wo [put God's water on their heads]; Asante-Twi and Akuapem-Twi - Mommo won asu [throw water at them]; Mfantse - Nnu won [dip/immerse them].

Konkomba - muin bi nnyun [put them deep in the water]; Hanga - su koom [bathe them]; Gonja - ka boreber [bath of God; give them the bath of God]; Dagbani - baptizibu (word coined from 'baptism'); Farafara - sôôra ba koom [bathe them with water].

The Dagaare translation, however, has korô ba suobu [continue bathing them]. The phrase is a command in the present continuous tense. This makes baptising a means of making disciples, which is the imperative of Matthew 28:19-20, the Great Commission.

From the analyses of the various translation above, it is seen that not all the Ghanaian mother tongue translations of the text under study are acceptable.

\section{Conclusion}

The various Ghanaian mother tongue translations of Matthew 28:19 render baptizontes variedly, to suit the indigenous Bible readers. They may have used religiocultural words and phrases that express a similar idea in their contexts to translate the word. This simply means that Bible translation, the science of changing an original biblical text from its primary form to another language for readers to understand its message, is not a straightforward exercise. Bible translation is not a word-for-word rendition exercise; it involves interpretation. Translators sometimes coin their own words or consult mother tongue speakers to render words and phrases that are difficult to translate. Bible translation is not a static venture; it is an ongoing exercise. This means that no mother tongue translation of the Bible is perfect, even though the messages they convey constitute God's message to the readers in their religiocultural contexts. This article has added to the interpretations of baptizontes from the Ghanaian (African) perspective.

\section{Acknowledgements}

The author acknowledges the following people: Paul Ekanwala Daboro, Samuel Sam, Solomon Dansieh, Samuel Zuul Bayeti, Paul Abdulai and Frederick Mawusi Amevenku.

\section{Competing interests}

The author declares that he has no financial or personal relationships that may have inappropriately influenced him in writing this article.

\section{Author's contributions}

J.E.T.K.-A. is the sole author of this article.

\section{Ethical considerations}

This article followed all ethical standards for research without direct contact with human or animal subjects. 


\section{Funding information}

This research received no specific grant from any funding agency in the public, commercial or not-for-profit sectors.

\section{Data availability}

Data sharing is not applicable to this article as no new data were created or analysed in this study.

\section{Disclaimer}

The views and opinions expressed in this article are those of the author and do not necessarily reflect the official policy or position of any affiliated agency of the author.

\section{References}

Barna, G., 2001, Growing true disciples, Waterbrook Press, Colorado Springs, CO. Beasley-Murray, G.R., 1962, Baptism in the New Testament, Eerdmans, Grand Rapids, MI.

Bediako, K., 1995, Christianity in Africa: The renewal of a non-western religion, University Press, Edinburgh.

Biblia, 2010, The Bible in Ewe, rev. edn., Bible Society of Ghana, Accra.

Bowland, T., 1999, Make disciples, College Press Publications, Joplin, MO

Douglass, J.D \& Tenney, M.C., 1999, NIV compact dictionary of the Bible, Zondervan Publishing House, Grand Rapids, MI.

Ebore Be Kawol, 1984, The New Testament in Gonja, International Bible Society, Accra.

Ekem, J.D.K., 2003, 'Biblical exegesis in an African pluralistic context: Some reflection', Journal of African Christian Thought 6(1), 31-34. https://doi.org/10.1353/ ral.2003.0013

Ekem, J.D.K., 2011, Early scriptures of the Gold Coast (Ghana): The historical, linguistics and theological settings of the Ga, Twi, Mfantse, and Ewe Bibles, Edizioni di storia eletteratura/St. Jerome Publishing, Rome.

Kpobi, D.N.A., 2008, Mission in Ghana, Asempa Publishers, Accra.

Kuwornu-Adjaottor, J.E.T., 2012a, 'Doing biblical studies using the mother-tongue approach', Journal of Applied Thought 1(1), 55-80.
Kuwornu-Adjaottor, J.E.T., 2012b, 'Mother-tongue biblical hermeneutics: A current trend in biblical studies in Ghana', Journal of Emerging Trends in Educational Research and Policy Studies 3(4), 575-580.

Kuwornu-Adjaottor, J.E.T., 2015, 'African biblical hermeneutics: A methodology for mother tongue biblical hermeneutics', E-Journal of Religious and Theological Studies 1(2), 1-24.

Kwarteng, K.S., 2020, 'Examining the challenges of discipleship in the Methodist Church Ghana', MPhil thesis, Kwame Nkrumah University of Sciences and Technology.

Kyerâw Kronkron, 2012, The Bible in Akuapem-Twi, Bible Society of Ghana, Accra.

Loba-Mkole, J.-C., 2013, 'The significance of Bible translation for African theological education', in I.A. Phiri \& D. Werner (eds.), Handbook of theological education in Africa, pp. 508-522, Cluster Publications, Dorpspruit.

Malulele, T.S., 2005, 'Half a century of African theologies: Elements of the emerging agenda for the twenty-first century', in O.U. Kalu (ed.), African Christianity: An African story, pp. 488-489, Department of Church History, University of Pretoria, Pretoria.

McKnight, S., 1991, A light among the Gentiles, Fortress, Minneapolis, MN.

Mojola, A., 2013, 'Bible translation and Christian theological education in Africa: A historical and Pan-African overview', in I.A. Phiri \& D. Werner (eds.), Handbook of theological education in Africa, pp. 486-499, Cluster Publications, Dorpspruit.

Naaåmen Nôpaalaa Gane, 2014, The New Testament in Dagaare, Bible Society of Ghana, Accra.

Naawun Bukupali, 1983, The New Testament in Hanga, International Bible Society, Accra. Naawuni Kundi Kasi, 2011, The Bible in Dagbani, Bible Society of Ghana, Accra. Ngmale Kroåkroå Lâ, 2006, The Bible in Ga, rev. edn., Bible Society of Ghana, Accra. Ngmami Klôuklôu ô, 1999, The Bible in Dangme, Bible Society of Ghana, Accra.

Nwoma Kronkron, 1974, The Bible in Mfantse, rev. edn., Bible Society of Ghana, Accra. Obeng Adjei, S., 2013, 'Matthew 28:18-20 concept of discipleship and the class system: A study of the Effiduase Diocese of the Methodist Church Ghana', MPhi thesis, KNUST.

Olowe, A., 2009, Missional reformation for discipling nations, Omega Publishers, Jackson, MI.

Sanneh, L., 2009, Translating the message: The missionary impact on culture, pp. 52-53, Orbis, Maryknoll, NY.

Togarasei, L., 2013, 'Biblical studies in theological education in Africa: Some methodological consideration', in I.A. Phiri \& D. Werner (eds.), Handbook of theological education in Africa, pp. 466-474, Cluster Publications, Dorpspruit.

Twerew Kronkron, 2017, The Bible in Asante-Twi, rev. edn., Bible Society of Ghana, Accra. Uwumbôr Aagbaå, 2014, The Bible in Konkomba, GILLBT/Wycliffe, Tamale. Yenâ Gôåô, 2007, The New Testament in Farafara, Bible League, Accra. 